Portland State University

PDXScholar

Engineering and Technology Management

Student Projects

Fall 2006

\title{
India's Rise as a Software Power: Governmental Policy Factors
}

\author{
Tad Drozdowski \\ Portland State University \\ Hai Huynh \\ Portland State University \\ Brian Lininger \\ Portland State University \\ Yicheng Peng \\ Portland State University \\ Naruedom Sakulyong \\ Portland State University
}

Follow this and additional works at: https://pdxscholar.library.pdx.edu/etm_studentprojects

Part of the Software Engineering Commons, and the Technology and Innovation Commons Let us know how access to this document benefits you.

\section{Citation Details}

Drozdowski, Tad; Huynh, Hai; Lininger, Brian; Peng, Yicheng; and Sakulyong, Naruedom, "India's Rise as a Software Power: Governmental Policy Factors" (2006). Engineering and Technology Management Student Projects. 1112.

https://pdxscholar.library.pdx.edu/etm_studentprojects/1112

This Project is brought to you for free and open access. It has been accepted for inclusion in Engineering and Technology Management Student Projects by an authorized administrator of PDXScholar. Please contact us if we can make this document more accessible: pdxscholar@pdx.edu. 


\title{
India's Rise as a Software Power: Governmental Policy Factors
}

\author{
By: \\ Tad Drozdowski, Hai Huynh, \\ Brian Lininger, Yi-Cheng Peng, \\ Naruedom Sakulyong
}

\begin{abstract}
The Indian government's policies toward an open, global market, support of educational institutions, and enhancement of appropriate infrastructure helped enable their software industry to become critical components of India's economic growth in the 1990s. The Technical, Organizational, and Personal perspective (T, O, and P) model is utilized to examine different affects that each perspective, inclusive of government policies, has on a socio-technical system (Software development in India). The Indian government has provided substantial economic liberalization to support their software industries, though continued reform is necessary to ensure that they remain a software superpower.
\end{abstract}

Keywords: Information Technology, Software Power, Government of India

(c) 2006 Portland State University: Engineering \& Technology Management.

Course: EMGT 520/620

Professor: Dr. Dundar F. Kocaoglu

Assistant: Pisek Gerdsri

ETM 


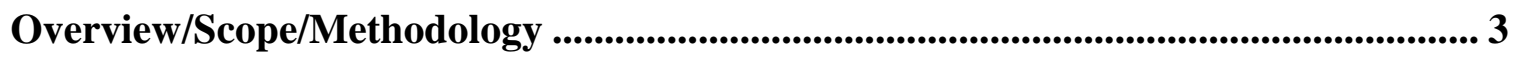

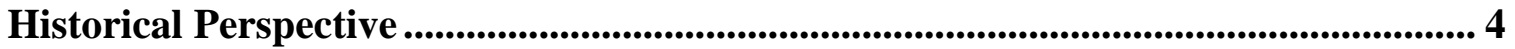

Technological Development of the Indian Software Industry ....................................... 7

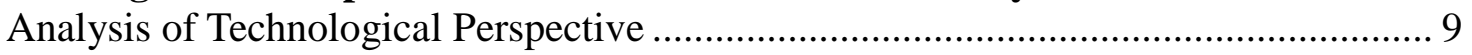

Technical Perspective Recommandations ..........................................................11

Organizational Development of the Indian Software Industry .................................... 12

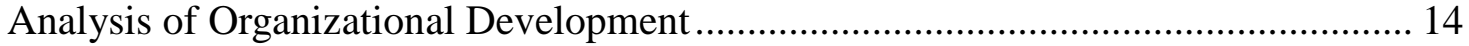

Organizational Perspective Recommendations....................................................... 15

Personal Perspective in Education Development of the Indian Software Industry.. 16

Analysis of Personal Perspective ......................................................................... 17

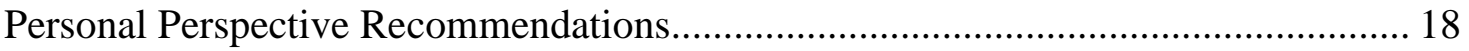

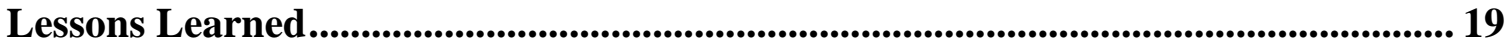

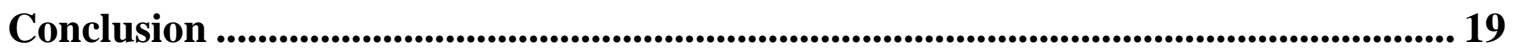

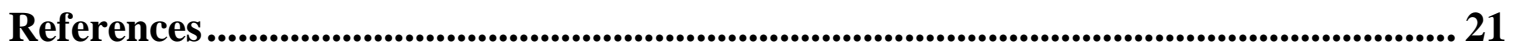




\section{Overview/Scope/Methodology}

The emergence of India as a software power is like an amazing transformation of a land of snake charmers to a land of software soldiers [18]. The software industry has become a critical component of India's economic growth. Software exports went from a few million dollars in the 1990s to over a billion dollars in 2000s and are expected to rise seven-fold to $\$ 57$ billion by 2008 [12], [13]. The most commonly quoted reasons for this rapid growth in India includes an English-speaking work force, high levels of education, and low salaries. However, another important factor is the Indian government's policies toward an open global market and a large international network [17], [18]. Liberal governmental policy established internet access in many geographic areas in India, funded elite educational institutions, promoted use of the English language for international business, created a friendlier environment for foreign investment that subsequently curbed the affects of sending Indian nationals overseas for work, and encouraged industry standard certification for local businesses in order that they may expand into the international market.

The importance of the government's role for India cannot be underestimated. Even when people refer to the English-speaking work force and high levels of education when citing India's rise in the software industry, they overlook the Indian government's role in promoting these values. The other aforementioned policies implemented by the Indian government played a role in helping establish India as a power in the software industry.

Our tie to technology management is the $\mathrm{T}, \mathrm{O}$, and $\mathrm{P}$ perspectives on a socio-technical system [15]. T, O, and $\mathrm{P}$ perspectives are a simple methodology to analyze a complex socio-technical system. T stands for technical perspectives, analyzing the system purely on its technological merits. O stands for organizational perspectives, evaluating how the technology affects the organization both formally and informally. P stands for personal perspectives, seeking to understand how the technology affects individuals within the system [15]. We analyzed each perspective and its affect on the present state and also the future state of the software industry within India. The following figure shows the T, O, and $\mathrm{P}$ model. 


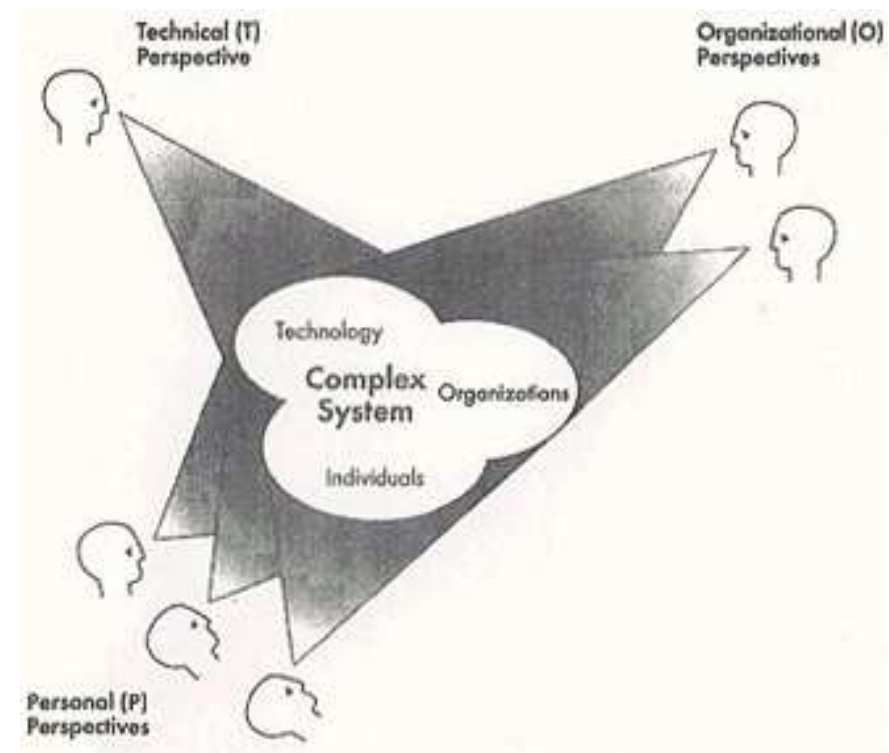

Figure 1: $T, O$, and $P$ perspectives on a complex socio-technical system.

\section{Historical Perspective}

\section{Liberalization of Indian Economy}

A dramatic shift in governmental policy like India's from one of economic isolation to one of international and economic cooperation does not occur over a matter of a few years. The well-known, substantial liberalization policies of 1991 were a combination of visionary leaders and external influences over four decades. The following short analysis will provide a broad context around which to understand the changing political and economic climate that the software industry operated under from 1947 to 1991, and a few substantial, executive policies made by the government, post-1991.

Following independence from Great Britain in 1947, India established an economy based around the concept of self-reliance (similar to the Soviet Union). The central government controlled all economic decisions and subsequently banned most imports. The government felt this type of policy was in the best interests of the population in order to encourage domestic economic activity [11].

During the 1970s, Indira Ghandi initiated reform to diversify the nation's economic base and provide growth for private companies in as many sectors as possible. Priority was given to the financial sector to provide increased investment. Many privatized sectors were able to take advantage of the infrastructure created by the government when they were under public control [11]. Even though local, privatized companies were allowed to grow, Ghandi initiated the protectionist policy, Foreign Exchange Regulation Act of 1973. This allowed foreign firms to only operate in India with a minority part of company ownership (40\%) [8]. Therefore, some reform was initiated towards privatization, but not in internationalization. 
Following her assassination, her son, Rajiv Ghandi was Indian Prime Minister from 1984 to 1989. He further implemented his mother's vision of a better India through economic reform. His highest priority was modernizing the economy through computers and telecommunications [11]. He implemented the New Computer Policy (NCP-1984) "which consisted of a package of reduced import tariffs on hardware and software (reduced up to 60\%) and recognition of software exports as a 'de-licensed industry" [8, p.17]. The very next year, export revenue was exempted from income tax. The 1986 Policy on Computer Software Export, Development, and Training "allowed the import of foreign software into the country for the first time" [24, p.11]. This policy also helped the establishment of Software Technology Parks (STPs) which will be discussed later. Additionally, he sought to create closer working relationships with Western governments and established nationalist policies meant to foster competition in their economy [11]. During the 1980s, Texas Instruments (1985), Microsoft (1987), and Nortel (1989) came to India to start operations, thanks to the friendly environment [24].

Even though political leaders supported some economic reforms, it was external factors in 1991 that provided the impetus for an overhaul of their economic system. Due to the 1991 Gulf War and the collapse of the Soviet Union, financial support and exports sharply decreased for India [25]. They were forced to utilize Gold reserves, which damaged their credit rating with all international banks. Given their struggling economic condition, India applied for a structural adjustment loan from the IMF and the World Bank [25].

As a result of conditions set by the loan, substantial reform followed the events of 1991 . There were "significant reductions in import tariffs and elimination of most import quotas, elimination or reduction of restrictions on foreign ownership, currency convertibility on the trade account, reduction in licensing requirements, regulations and red tape, opening most industries except six to private ownership and reduction in domestic excise taxes, among others" [11, p.78]. Foreign investment could be now up to $51 \%$ of equity without any governmental permission (up from the maximum of $40 \%$ ). Financial markets were liberalized in order to increase investment in the economy of India. Businesses continued to flood in and many large, profitable companies came from the around the world. They came from countries such as the United States (companies included General Electric, Coca-Cola, Motorola), England, Japan, and Germany [11].

There have been large policy initiatives undertaken since 1991 directly related to the software industry. One was the formation of the Ministry of Information Technology (MIT) in 2000. Until this high-level position was formed for IT, there was no central point for national policy formulation related to IT [19]. Instead, many smaller IT-related agencies were under the Ministry of Science and Technology [19]. By realizing that the IT industry was becoming a powerful force for the Indian Economy, the government strengthened this issue's position in the political arena by developing the MIT [19]. Due to the tremendous affect that outsourcing had on the Indian population, the government started a High Level Committee on the Indian Diaspora in 2000 [19]. The government encouraged Indian nationals that had leadership positions in large firms overseas to come back to India and engage their companies to employ or contract with Indian companies 
[19]. They also encouraged Indian nationals in overseas corporations to participate in short term consultancies via the Transfer of Know-how through Expatriate Nationals (TOKTEN) program [19].

\section{CMM-SW}

CMM-SW is a critical component in the world today that establishes a competitive benchmark for which to judge the technical abilities of software companies. Our paper includes the CMM-SW classification and its affects on Indian software companies. The following description provides a background for the origins of CMM-SW, and its global impact on the software industry.

During the 1980's, there were many large software projects in the United States, as well as abroad, which experienced significant to catastrophic failures in delivery or function. The US government, in particular the Department of Defense (DoD), had experienced a significant number of these failures. Regional and state governments were not immune to these failures either, as evidenced by these failed projects: an updated database system for the California Department of Motor Vehicles and the baggage handling system for the Denver Airport [10].

At the same time, the demand for these large software systems was growing. The power of the computer had taken hold and now the race had begun to implement systems that could eliminate our dependence on human-intensive systems for repetitive work. However the Software Engineering field was just emerging as a specialized discipline of systems engineering, and knowledge in the field of large system development was scarce [14].

This led to the development of the Capability Maturity Model for Software (CMM-SW) by the Software Engineering Institute (SEI) at Carnegie Mellon University during the early 1990's [14]. The purpose of the CMM-SW was to define a set of guidelines that could be used to evaluate the software engineering processes of a company. It had a single number (1-5) ranking system that simplified the process of evaluating the capabilities of a software development organization.

By 1993, the DoD had adopted the use of the CMM-SW in all of its software contracts, requiring at least a Level 3 certification [14]. This adoption by the DOD vaulted the CMM-SW into the forefront of software maturity models and spread awareness within the software systems market of its importance [14]. The CMM-SW finally gave companies a way to evaluate the capabilities of software development companies worldwide, which would prove to be a major factor in the explosion of software development in India.

\section{Y2K Software Defect}

Because of the state of India's software and hardware industry at the time of the worldwide Y2K problem, they were able to help solve the problem and promote their indispensability as a software power. Since this external event contributed to India's rise as a software power and is discussed in our paper, a historical synopsis is warranted. 
During the evolution of software development, many software systems were developed which are still in use today. Over that period, many different hardware and software technologies were used to develop these systems. The danger of having so many different technologies used in production systems is in the area of maintenance. When a change is necessitated to a system that is a technological generation, or more, behind the current generation, there is a significant risk that any changes made may do more bad than good to the system. This is a result of engineers who do not understand the pervious generation's technology, and thus do not fully understand the implications of their changes.

The Y2K software defect proved to be one such area where there were many systems still in use that had been developed using technology that were several technology generations behind the current state-of-the-art. It came to light in the late 1980's, and garnered international attention, as the extent of the problem was more fully understood [12]. The Y2K software defect had wide ranging potential impacts, as many of the legacy systems implemented had used the same fundamental assumption: storing the year of a date in two-digit format rather than all four digits. This had major implications for services ranging from automated billing systems to power distribution systems, as most of these systems were not designed to differentiate between 1900 and 2000 [12].

\section{Technological Development of the Indian Software Industry}

\section{Internet Access}

As technology increased in India, so did the desire for access to this knowledge. This desire helped move technological development throughout the country. The government played an important role in allowing the people of India the opportunity to obtain the technical knowledge.

Prior to the 1990s, India had a lack of communication infrastructure. For example, India only had "seven telephones for every 1,000 people compared to 490 per 1,000 in the United States" [1, p.2]. This demonstrates the lack of infrastructure available. Also, with small amounts of power, companies were forced to use leased links for most if not all of communications [1]. The shortage of resources hindered the beginning of the technology transfer to India. The government also placed restrictions which kept the Internet power in their hands until 1995, when this restriction was lifted [1].

Even with the restriction lifted, it did not allow India full access to the Internet. The state funded company, Videsh Sanchar Nigam Limited (VSNL), launched the first Internet Service Provider (ISP) in India in August 1995 [19]. This ISP was the only one in the nation and was the only source for Internet access [19], which did not put the people in India in a better situation then before the restriction was lifted. Only now, those who were wealthy were able to afford Internet service. Since wealthy people were the only ones connecting to the Internet, the service was more for leisure than for anything else [19]. 
In 1998, the Government ended VSNL's ISP monopoly and allowed other providers into the market [1]. Private companies began offering Internet service at a competitive price, which in turn released the Internet to the entire population of India. With this available resource, there was an increased demand for information technology in India. In a span of seven months, March to October 2000, the number of Internet subscribers doubled to nearly two million customers [1]. In 2003, the count of subscribers reached 23 million [1]. Other affects of the Internet included improved human rights and social conditions by expanding access to education and healthcare and also increased economic opportunities [19].

\section{Software Technology Parks}

Although the growth of the Internet and computer use grew in India, and is a noteworthy factor in the rise of technology in India, a more significant reason for this increase was the establishment of Software Technology Parks (STPs). These were a result of a policy document on "Computer Software Export, Software Development and Training", released by The Ministry of Information Technology in 1986 [7].

The Ministry of Information Technology understood that for the spread of IT knowledge to occur within India, there needed to be proper equipment, a good way to connect to the outside world, and a way to spread the new knowledge [19]. Understanding that strict restrictions on Internet access to citizens hurt technological innovation, the Ministry believed creating new policies could help guide the growth of technology [19]. If they could concentrate and create policies to allow for Internet connection and technology in designated cities, they could generate the needed technology growth [19]. This idea was later turned into a policy and the result of it was the creation of software technology parks [19].

Key objectives of STP [1]:

- Front-end to the software industry for the Indian government

- Provide consistent communication between industry and amenities

- Promote development of the software and service industry

- Train professionals and drive the rapid growth of technology within the country

The software technology park itself was a physical infrastructure created by the government with help from the Ministry of Information Technology [19]. This infrastructure included dedicated high speed connectivity, and necessary equipment for IT development [19]. By creating this organization and associated policies, India's intent was to bring "expertise on sophisticated computers" and allow this knowledge to be developed "duty-free" [19].

The first set of Software Technology Parks was created in 1991 at Bangalore, Pune, and Bhubaneswar. Eight years later over twenty cities had Software Technology Parks [7]. This demonstrates India's belief in central knowledge and infrastructure [7]. 


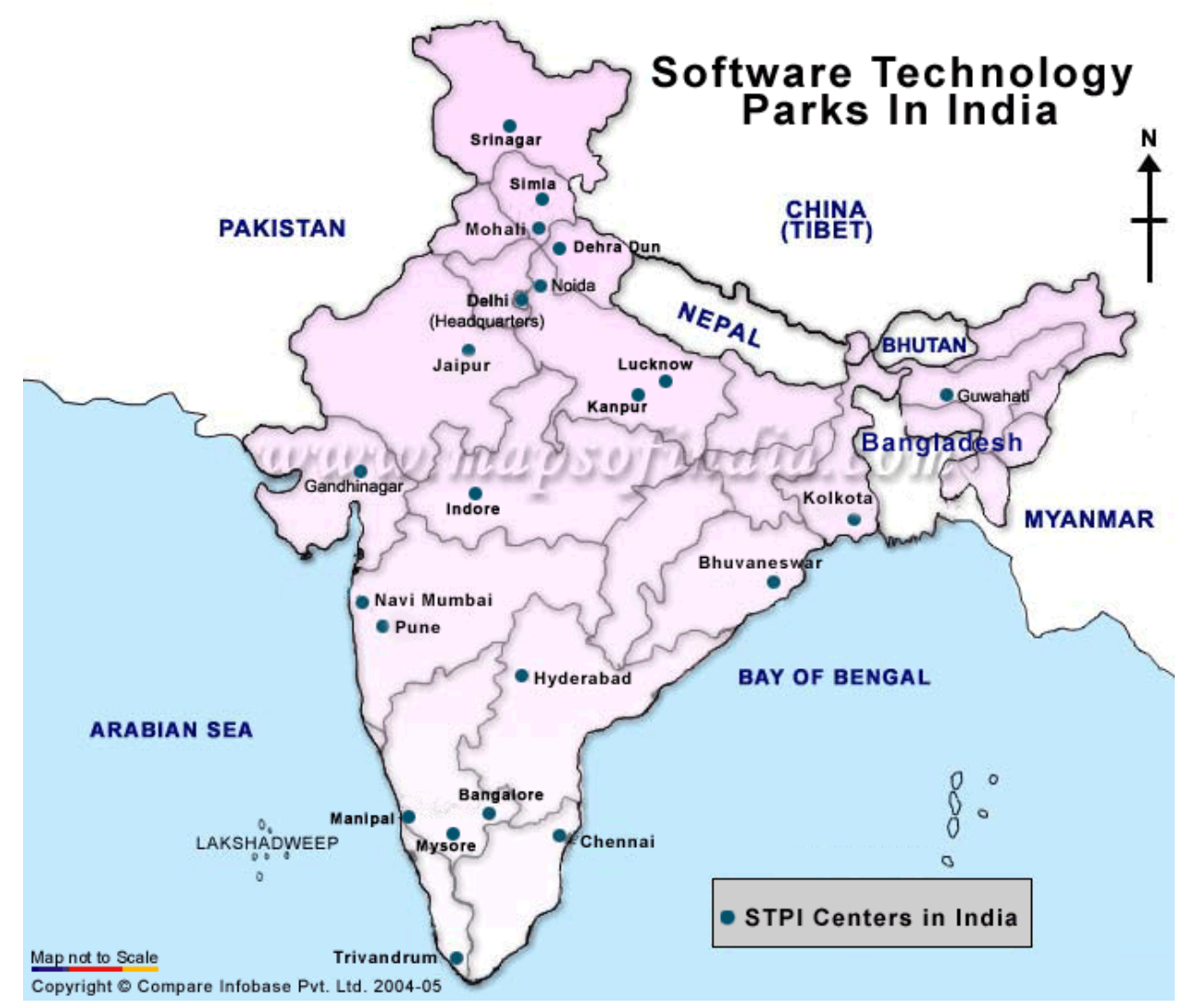

Figure 2: Software Technology Parks of India.

The creation of Software Technology Parks helped India unify as a country to become one of the leaders in software development. It allowed one point of clearance and approval, provided mobility to set up shop anywhere within India and most importantly had the backing of the government.

\section{Analysis of Technological Perspective}

Mary Mathew performed a study that looked at the rise of India as a software power and the affect on the country. Mathew determined it took two major generations to arrive at the innovation phase from the imitation phase. Looking more deeply at these two generations, four stages emerged. Each stage has evidence to show a pattern that Indian software is trying to move from imitation to innovation [16]. 


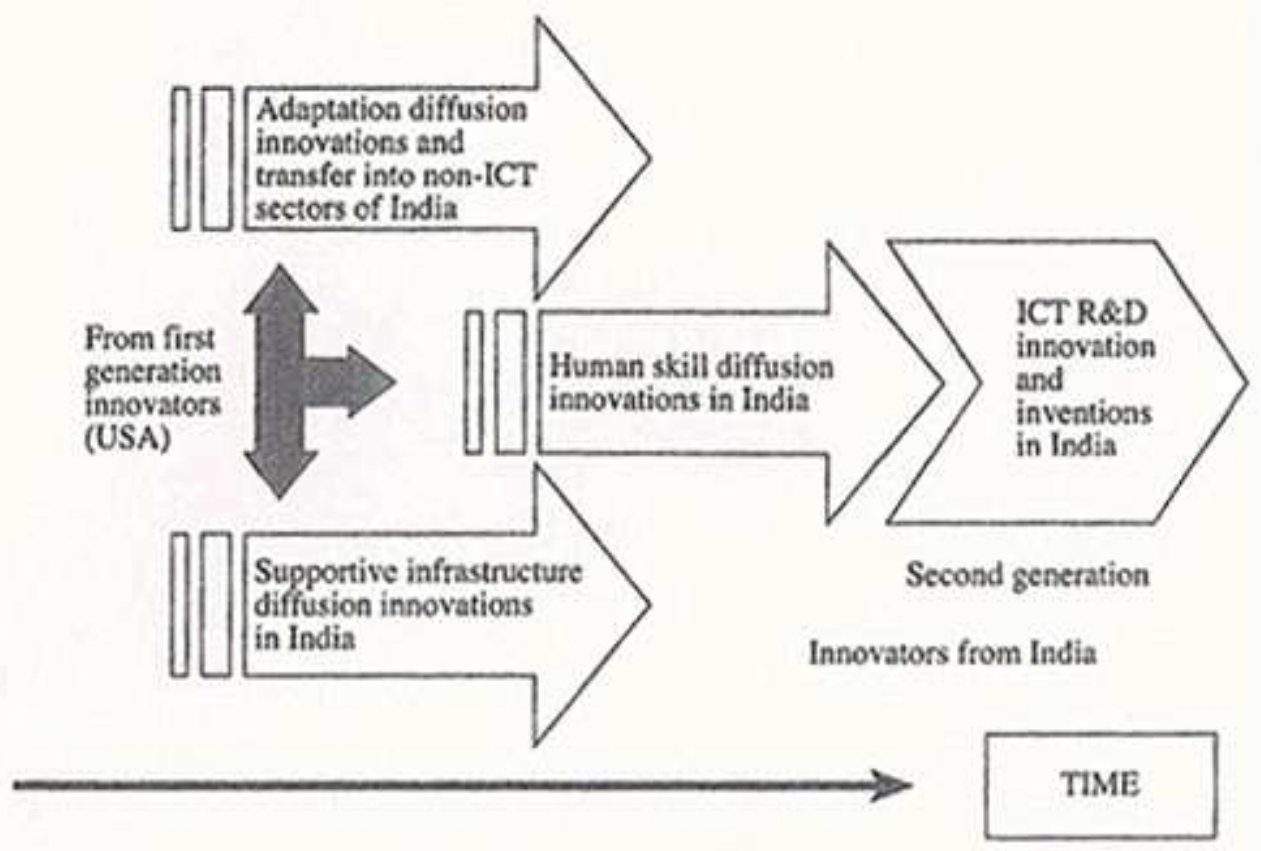

Figure 3: Development of Technology Generations.

The first stage was lead by Indian nationals coming to the United States and gaining better knowledge of the software industry. The Y2K bug was the foundation of this stage. By being submerged in the software industry, it helped many people learn how to program and create commercial software. As the Y2K bug was resolved, this left the Indians that came to the U.S. without jobs, returning to India. Looking at the Indian software industry in International exports during 2001-2002, the growth of software applications is mostly banking services, financial services and insurance systems. There are some software applications for manufacturing, telecom equipment and others [16].

As Indians moved back to India, they brought with them the knowledge gained from the United States in the software industry. This provoked the start of the second stage. With this knowledge and the involvement of the Indian government, stage two is the most crucial in the rise of India as a software power. The government developed STPs, which provided India facilities to develop software. Along side the STPs, the government also built network systems, helped increase Internet services, and transportation [16].

The new construction and involvement launched into the second generation - innovations in India. With knowledge and the proper tools, India is able to be a standalone country for developing software. India is able to focus now on fine tuning their software development process, which leads into the third stage, human skill improvement. Government, education and business focused on creating better awareness of software industry's needs, shifting from low-end software to higher-end and higher quality software, and focus on gaining high level software certifications [16].

Increasing standards in India's software development seamlessly moved the country into stage four - R\&D innovations in India. The U.S. Patent and Trademark Office show that 
there are 105 patents from 1980 to 2001 coming from India [16]. However, while many companies were located in Bangalore, they were not Indian companies.

While the trend of Indian IT tends to be that of a shift from imitation to innovation, there is a general agreement that $R \& D$ spending in Indian software industry is inadequate compared with the investments in the more developed countries [20]. Nageesh Kumar (2005) cites figures of $4 \%$ of their revenue for Indian companies in 2000-2001, with firms based in other countries investments ranging from 14-19\% of revenues [12]. Output for intellectual property is correspondingly low, with Indian software firms generating less patenting activity than foreign firms operating in India. Hence, the Indian software industry tends to innovation but they are less actively working to create a new product or service than their competitors in more developed nations [20].

\section{Technical Perspective Recommendations}

Technology transfer is a way to get ideas and innovation from federal research and university-based development to public and private needs. It is a process by which to take existing knowledge and create a new product or service. Here are three possible degrees of technology transfer [23]:

1. Knowledge. The technological innovation goes into public discussion so business becomes aware of it.

2. Use. The technological innovation is put in use in existing organizations.

3. Commercialization. The innovation is put into a new product and taken to the marketplace.

The Indian government could increase the investments to their federal R\&D laboratories and state universities, making a larger share of R\&D public knowledge. They could increase numbers of laboratories and research centers to spread their R\&D in the highly IT developed states. The Indian government could enhance the technology transfer and make more formal connections between their R\&D, public needs, and businesses. The government could not only develop their R\&D but also help business understand why and how technology transfer could benefit them.

Now that the Indian software industry is recognized globally as a force in that industry, it must continue to keep pace with respective developments. Currently, the Indian software industry is an imitator, not an innovator. Based upon 1999 figures, India is spending only $0.35 \%$ of its Gross Domestic Product (GDP) on IT [21]. The United States by comparison spends $4.14 \%$ of its GDP on IT, nearly 12 times the investment [21]. The amount of resources allocated to research and development for software must increase for the Indian software industry to remain competitive and truly become an innovator. 


\section{Organizational Development of the Indian Software Industry}

\section{Body-Shopping to Outsourcing}

When IBM left the Indian market in 1977, it left a large hardware market, into which several local companies tried to fill the void as a hardware supplier for the Indian people. Many of these companies expanded their services by offering software products and other services to diversify themselves. Some continued to produce both hardware and software products, but many realized that the software services arena held the promise of increased revenue and profits. These companies, many following in the footsteps of market-leader, Wipro, chose to focus their efforts on the software services market.

During the late 1970's and early 1980's, India's "state dominated, import-substitution industrialization strategy" [21, p156] had many policies that made for a hostile work environment for technology companies. This emphasis on self-sufficiency and selfreliance manifested itself in high import tariffs and as there were few computer hardware manufacturers at this time, procuring computer hardware was difficult and expensive.

Due to these factors, most of these companies found it easier to send their programmers to their customer sites. This practice became known as "body-shopping", as software companies who hired these Indian programmers were simply "shopping" for "bodies" to write computer code at a cheap price. The Indian programmers were more than happy to do this work as they could easily earn more money in a couple months of work than they would in an entire year at home in India [26].

The rise of "body-shopping" occurred for two primary reasons. The first reason was the software crisis in the United States, when software projects were commonly overrunning their budgets by $100 \%-200 \%$, so companies were looking for ways to save money on their software project costs [14]. The "body shopping" Indian programmer could fill this need for cheap programming labor for the US companies.

The second reason was the $\mathrm{Y} 2 \mathrm{~K}$ defect. As we saw earlier, the $\mathrm{Y} 2 \mathrm{~K}$ defect affected a great number of the software systems developed world-wide. There was a great need to fix these legacy systems, however the skills for this work was in short supply as the programmers in the United States and Europe were skilled in the latest software development technologies; there were simply were not enough people to complete the work necessary to fix these legacy systems.

One effect of India's self-reliance polices which lasted through the 1970's was that there was little current computer software or hardware technology for Indians to work on. Instead, they worked on technology that was a generation or two behind the rest of the world. This was exactly the skill and experience that companies were looking for to help them solve their problems. India had a large market of cheap labor that had a set of skills that were in great need to fix their existing legacy systems. 
As the environment became friendly to business in the late 80's and 90's, the trend shifted from "body-shopping" to outsourcing, the act of work being done overseas by foreign companies. Indian engineers began doing more and more work in their home country as it became cheaper and easier to do work remotely. It became easier to do because of India's investment in telecommunications infrastructure as well as new developments in software engineering, which allowed for software to be designed as separate pieces, developed independently and then integrated together to produce the final product.

Another factor in this shift to outsourcing was the economic slowdown in the early 1990's. The huge demand for programmers to fix the Y2K defect began to diminish in the late-1990's as these defects were fixed, and combined with the economic slow-down which was occurring, the need for these Indian programmers declined and many returned to their home country.

\section{CMM-SW}

In India, the software services company Wipro initially adopted the CMM-SW. At the time of its release, Wipro recognized that the CMM-SW was a pacing technology that could give it a competitive advantage for software contracts with companies in the United States. In 1991, Wipro became the world's first CMM-SW Level 5 certified software services company [14]. By adopting the CMM-SW, Wipro had distinguished itself not only form the other Indian software service firms, but also from the majority of software service firms around the world. Over the next decade, Wipro used this advantage to earn "scores of research and development contracts from blue-chip clients" worldwide [14, p 4].

After seeing the huge success that Wipro had after adopting the CMM-SW and receiving a Level 5 certification, many of the software development firms in India proceeded to pursue a CMM-SW certification. By March, 2003, about 51 Indian software companies had received the CMM-SW Level 5 certification, which represented more than half of the CMM-SW Level 5 certified companies in the world [12]. To remain competitive with Wipro, many companies have found it to be an absolute necessity to pursue a CMM-SW certification. Many of the software engineers in India now will only work for a company which either is, or is actively pursuing, a CMM-SW Level 5 certification. It has become a mark of distinction for India's software engineers to work for a CMM-SW Level 5 certified company. It has become a necessary item for their resume if they wish to come to work in the United States, where wages are still many times more lucrative [26].

The Indian government has recognized how these pacing technologies have contributed significantly to the rise of the Indian software industry. The "quality movement" is being pushed by the Indian government through initiatives such as the Indian Ministry of Information Technology's licensing arrangement with SEI to encourage Indian companies to pursue software quality certifications [12]. In addition, the Directorate General of Foreign Trade in the Ministry of Commerce will provide special software licenses to companies that have received a CMM-SW Level 2 Certification [12]. These 
polices reinforce the Indian "quality movement" and will continue the advance of the Indian software industry as a power in the global software market.

\section{Analysis of Organizational Development}

\section{Body-Shopping}

The phenomenon of "body-shopping" was a result of the harsh business environment of India during the 1970's and 80's. During the 1990's we saw the government's attitude towards business change, and combined with the economic slowdown, many Indian engineers returned from overseas work. During 1990-91, 90\% of India's software services were "body-shopping", whereas only 5\% was offshore software service work [21]. In 2002-03, 39\% of the software services were "body-shopping", whereas 58\% was offshore work [21].

One effect that "body-shopping" had on India's software industry was to "spread the word." When India's software services industry sent their engineers overseas for contract work, they sent their best and brightest engineers. This gave these contracting companies experience with the Indian IT worker, and many made a positive impression. It was this positive impression that drew foreign companies to explore the Indian software market when the business climate changed in India.

However, this was a side effect to the isolationist policies of the Indian government in previous decades, but it turned out to be a positive influence on the development of the Indian software industry. It was not a targeted result directed by government policy, but rather a by-product of it that worked in the software industry's favor.

While the harsh climate towards foreign companies ultimately worked out for the Indian software industry, it could have very well turned out much differently. The self-reliant polices of the Indian government in its early years kept foreign technological advances from entering the country. Without this technology infusion, the software industry of India remained a technological generation behind the rest of the software industry. It was by fortunate coincidence that the $\mathrm{Y} 2 \mathrm{~K}$ defect brought about a new market for the Indian software engineers' skills in legacy systems.

\section{CMM-SW}

The CMM-SW gave those software companies who achieved a certification a way to compete with other software companies in the global market. While many companies that were located in the United States and Europe had already established a reputation for software quality, the companies in India were new to the global software market and needed a way to differentiate them. In many ways, the CMM-SW certifications gave Indian software companies a "leg-up" on other software companies because non-Indian software companies that were not primarily doing work for the DoD did not actively seek to get a CMM-SW certification. In fact, more than half of the software companies today do not have a CMM-SW certification and they do not have any particular interest in obtaining one. This is due to the majority of software companies developing mass- 
produced software rather than custom software solutions for companies, as well as the established reputations of existing companies.

India's software industry grew rapidly because they pursued a mean to distinguish themselves from their competitors. They were able to distinguish themselves from other software companies through the CMM-SW, as it was an independent qualification of the quality a customer could expect to receive in their software. While other software companies were content to rely on their reputation as an indicator of software quality, India's software industry sought independent certifications that could be compared to companies around the world, including those in the established markets like the United States. The Indian government has realized this importance and supported initiatives related to this "quality movement." They realize and are adopting the "imperative in technological innovation." As Betz asserts, "the imperative in technological innovation is that superior technology of a competitor cannot be ignored by other competitors, except at their peril" $[6, p 8]$.

\section{Organizational Perspective Recommendations}

\section{Outsourcing and Beyond}

Balancing the needs of a country to modernize so that it can be globally competitive is a delicate balance of give and take with foreign investments. Without the knowledge and skills that come with foreign investments, a country will take much longer to progress if left to its own means. At the same time, foreign companies should not be allowed to exploit the resources of a country that is not as advanced.

India's software industry remained a technological generation behind the rest of the world until recently. With the easing of restrictions on foreign investments, global software companies have infused current software technologies into the Indian software industry. This change in government policy has led to a balance between the need by foreign industry for India's cheap resources, namely labor, and the need of the Indian people for technological advancement.

An example of this balance is the Japanese. After World War II, they had to rebuild their country and their industries. Their country was ripe for exploitation by outside industry, but a balance was achieved through careful planning of government policy. Foreign companies were not allowed to come and exploit their resources; these companies had to train the people in the science and technology of the work they were doing. This allowed foreign companies access to these new markets and resources, but the Japanese society quickly learned the science and technology that these companies had developed. As a result, they eventually were able to turn this new knowledge into better products that competed with the foreign companies.

Without the foreign investments of industry, both Japan and India would have been left in the technological "dust" of the rest of the world. It is through the application of government policy that the balance between technological advancement of a society and 
the exploitation of resources can be managed. We recommend India's government continue to exercise this delicate balance in its future policies.

\section{CMM-SW}

To remain globally competitive, the Indian software industry must maintain and further its ability to "signal" the world that it is keeping pace with the global software industry [4]. Much in the same way that Wipro first used the CMM-SW as a pacing technology to show that it was competitive with even the best software companies, new pacing technologies will have to be found and adopted to keep India's software companies competitive.

Recently SEI integrated two competing software maturity models into the Capability Maturity Model Integration (CMMI) [4]. This integrated model focuses not only on correct software practices, but also on integrating software process improvement practices. In addition, SEI also developed the People Capability Maturity Model (P$\mathrm{CMM}$ ), which is a certification of the processes used to develop and manage their workforce. In order to continue their pacing the global software industry, the Indian government should continue to help/encourage software organizations to pursue these certifications.

\section{Personal Perspective in Education Development of the Indian Software Industry}

During colonization, the British government adopted higher education in European style and established several universities in India from about the mid-1800s to the mid-1900s. Although these universities were declared to be for higher education, they were designed for colonial control [2]. This design did not allow for quality education. In order to preserve their control over India, the British government introduced India to European culture and educated them only in the disciplines of law, medicine, and teaching [2]. Under British rule, they produced Indian talent to serve the British administration. As a result, the knowledge of technology and sciences were ignored. In addition, the British government abandoned India's traditional learning system. At the time, the English language was used to instruct for all university education [2].

Although the European education model limited the knowledge of learning, it did impact India's Personal Perspective. The Indian population realized higher education was a chance to get better jobs under the British administration. That, and the English language, allowed for easy access to European society [2].

After independence from Great Britain in 1947, the Indian government wanted to move from a poor colonial nation to an advanced nation. Education reform was the first option because this created talents and human resources for economic growth. The Indian government stated they wanted to develop education to advance knowledge in technology and science [2]. There was several world class institutes established such as the Indian Institutes of Technology (IIT). Also, lots of universities and colleges were founded that 
produced a large amount of technology manpower. The educational institutions created a large pool of science and technical personnel to help develop the Indian software industry [2].

Creating these highly educated people was important in supplying the workforce of the software industry but many Indian software engineers migrated abroad to the western world. The Indian software industry was still not growing enough to take all the manpower [12]. This resulted in the "brain drain" phenomenon that started around 1964 [12]. The Indian government placed a lot of investment on higher education, but received low return of investment in making these technological engineers serve their own country [12]. Although the brain drain opened employment in the global market, the Indian software industry lost many valuable software engineers. The tie to the Personal Perspective is that during the brain drain, an individual looked out for what was best for them by getting a job where the market paid the best salary instead of staying within their own country for employment.

In order to reduce the brain drain, the Indian government not only continued to enhance higher education but accelerated the growth of software industry. They increased capital and financial support for the software industry [12]. They built infrastructures including roads, buildings, and software technology parks [12]. Therefore, job opportunities increased. Many Indian software workers stayed in India because of the improvement in the environment of the software industry. In addition, some senior software professionals that were part of the brain drain wanted to return to India and start their own companies [12].

Bangalore is known as the Indian Silicon Valley. The Indian Statistical Institute and the Indian Institute of Science are two important educational institutes in pure science located in Bangalore [5]. Many Bangalore software firms recognized the role of academic institutions as key suppliers of labor. The academia-industry linkages are very diverse in Bangalore. The local academic institutions provide skilled people as well as providing human resources for many software firms [5].

\section{Analysis of Personal Perspective}

As more attention was paid to higher education, lots of universities and colleges were founded that produced a large amount of technology manpower for the Indian software industry. While these increasing technology programs were good, there were several potential issues regarding a lack of quality control [2].

In order to produce many technological engineers, colleges and universities would get as many as students they could. However, most of the technological courses were overfilled. For example, a course could have more than five hundred applicants per class. This would make it difficult for an instructor to interact with every student. The instructor might make the course easy going when there were so many papers or programming projects that need to be graded. On the other hand, because the software industry was 
important in India, the demand of software engineers increased each year. This led many engineering students to apply to the software major because it had a high possibility for employment after graduation. Many students tended to an attitude to register for the technology courses in order to get future jobs. These students took software courses because of program's requirements. Many do not care what they learn, rather they just want to finish the degree [2].

There are drastic variances in the education of engineers in India. There are a lot of 'weekend' schools that Indians try to pass off as full college degrees in order to get programming jobs [3]. This is a huge issue for companies because they could not get quality programmers out of the large pool of 'educated' labor [3]. Also, the turnover rate was very high because the 'quality' people were in such high demand [3].

Both McKinsey \& Co. and Nasscom recently (Dec 2005-Feb 2006) released new studies to give a warning of India's IT labor shortage in the next five years [22]. By 2010, India's revenues from outsourcing are expected to be $\$ 60$ billion, and they are expected to require 150,000 IT engineers and 350,000 business-process staff [22]. Engardio points out that without updated infrastructure and a better education system, India's outsourcing industry faces a labor shortage [9]. Rai noted that there are about three million college graduates and nearly 400,000 engineers every year, but not all of them are ready work at international standards [9]. Engineers that graduate from lesser quality schools had weak English speaking skills [9].

English is not the native language spoken at many colleges in India. Most of India still speaks one of its native languages. The Indian Institute of Technology (IIT) and Regional Engineering College (REC) are good quality schools, whereas other schools don't have as good quality control [3].

Another potential problem is that young college graduates still have multiple choices to work outside of the outsourcing industry in other countries like the United States. If Indian software talent is scarce, companies will go wherever the labor pool is available. This includes Eastern Europe and China. The current infrastructure is already strained to the limit and there are still some poor conditions of India's infrastructure as a whole that slow the international competitiveness of business [9], [22]. Therefore, if both software industry labor levels and the general environment of the country cannot meet supply and demand, there are significant negatives in the Personal Perspective of the TOP analysis.

\section{Personal Perspective Recommendations}

India has a large human resource pool in their population but there are large numbers of graduates not ready to work with international partners. In addition, as the software industry sector grows, most companies tend to hire engineering masters and $\mathrm{Ph}$. $\mathrm{D}$. students to improve their quality of software products or services. Therefore, the key improvement from the Personal Perspective is to increase education and training in both quality and quantity. The Indian government should support the education system by 
developing different teaching methods so that instructors can be effective for different types of students. Furthermore, they can enhance the investment to improve the quality of basic education in small towns and rural areas, especially the need to enhance the English language in these areas [4]. This, coupled with Kondratieff's observations that technological innovations expand the economy of the country, should begin to close the disparity between the rich and the poor and create a better environment for software industry growth [6].

\section{Lessons Learned}

When it comes down to dissecting the performance of the Indian government in relation to its rise as a software power in the world, their ability to provide basic necessities was essential to their success.

A vibrant economy and associated health of industries cannot be achieved through only market forces. Government plays a key role in stimulating the economy through involvement in many diverse aspects of the socio-technical system as evidenced by our analysis (via technical, organization, and personal avenues). In India's case, it is promoting policies for the importance of education, CMM, and marking sure that infrastructure is developed (STPs and internet access). They do not need to tell professionals what to do, but, they must give them the tools and support necessary to do it.

While "support" and "tools" are buzz words that may sound like a campaign for a politician, it is important even though some benefits are realized right away (direct) and some are not (indirect). For example, two such ways the government provided support was via financial support of the education system and providing tax breaks for aspiring, young companies competing in a global economy. Tax breaks are economic benefits that have a direct financial impact for the business and its parent industry while educational support provides a more indirect affect on the economy as the results of education are intangible and not immediately recognized. The benefits of the other factors in the favorable economic climate have a mix of the direct and indirect measures of support as mentioned above. Regardless of the direct or indirect consequences of policy, government must support the economy and the people and implement policies as such. Without that support, the country will not allow for successful industry in a world centered on technological change and industry's ability to respond to that change.

\section{Conclusion}

From the 1970's through 1991, India made incremental advances to liberalize their economy and focus on cooperation and competition with the international community instead of isolating themselves from it. External influences propelled India to make drastic changes in 1991. These changes continued throughout the rest of the decade, created a favorable environment for the software industry and propelled India to be a 
software superpower. India must maintain a clear focus, a commitment to change and implement meaningful policy with the urgency of 1991, but, with the long-term, internal vision and purpose of the 1970s and 1980s in order for it to remain a software giant in a globalized world. 


\section{References}

[1] Allision, T., "Software - the Arrowhead of India's IT Weaponry", Asia Times Online, http://www.atimes.com/reports/BL07Ai01.html, Dec 2000.

[2] Altbach, Philip G., "Higher Education in the $21^{\text {st }}$ Century: Global Challenge and National Response", IIE Books (Institute of International Education), pp25-36, Annapolis Junction, MD, Apr 1999.

[3] Anonymous Source (Con-Way Enterprise Services), Personal Interview by YiCheng Peng, 04 November 2006.

[4] Athreye, Suma S., , Saith, Ashwani and Vijayabaskar, M., "Human Capital, Labour Scarcity and Development of the Software Services Sector", ICTs and Indian Economic Development, California: Sage Publications Inc, pp123, 2005.

[5] Basant, Rakesh, "Bangalore Cluster: Evolution, Growth and Challenges", Indian Institute Of Management Ahmedabad (IIMA), pp11, Ahmedabad, India, May 2006.

[6] Betz, Frederick,_Managing Technological Innovation: Competitive Advantage from Change, John Wiley and Sons, Inc. Hoboken, NJ, 2003.

[7] Caso, E. and S. Kohler, "India: the Next Silicon Valley?", BT Alex Brown, Research (working paper), 1998.

[8] Dossani, Rafiq, "Origins and Growth of the Software Industry in India”, AsiaPacific Research Center, Stanford University, (working paper), Shorenstein Asian Pacific Research Center, http://iisdb.stanford.edu/pubs/20973/Dossani_India_IT_2005.pdf, Sept 2005.

[9] Engardio, Pete, “India’s Looming IT Labor Shortage”, Business Week, pp1-2, Dec 2005.

[10] Gibbs, W.W., "Software in Crisis," Scientific American, vol. 271, pp. 86-95, 1994.

[11] Kaushik, Surendra K., "India's Evolving Economic Model: A Perspective on Economic and Financial Reforms", American Journal of Economics \& Sociology, Vol. 56 Issue 1, p69-84, Jan 1997.

[12] Kumar, Nagesh, , Saith, Ashwani and Vijayabaskar, M., Ed., "Indian Software Industry Development: National and International Perspectives", ICTs and Indian Economic Development, California: Sage Publications Inc, pp96-101, 2005. 
[13] Kumar, Vipan, "Evolution of Information Technology and Its Emergence in India" Nistads News, Vol. 5, No.2, pp15-16, Oct 2003.

[14] Lahagu, Rolly, Capps, Brent, Lingareddy, Surendra, Mundanda, Naveen, and Sumitsawan, Wissanu, "Wipro and the Rise of the Indian Software Industry", Portland State University, http://projects.etm.pdx.edu/stdproject/2001/2001-F520-01-1.pdf, 2001.

[15] Linstone, Harold A., , Norwood, Bruce, E. Ed., Decision Making for Technology Executives: Using Multiple Perspectives to Improve Performance, MA: Artech House, p53, May 1999.

[16] Mathew, Mary, , Thatchenkery, Tojo and Stough, Roger R., Ed. "Diffusion Innovation: A Pattern of Information Communication Technology Innovation in the Indian Economy." Information Communication Technology and Economic Development: Learning from the Indian Experience. Massachusetts: Edward Elgar Publishing, Inc. pp87-101, 2005.

[17] Meyer, Bertrand and Zurich ETH., "The Unspoken Revolution in Software Engineering", IEEE Xplore, Vol. 39, Issue 1, pp122, Jan. 2006.

[18] Moitra, Deependra, "India's Software Industry", IEEE Xplore, Vol. 18, Issue 1, pp77-80, Jan/Feb 2001.

[19] Nagala, Sarala, "India's Story of Success: Promoting the Information Technology Industry", Stanford Journal of International Relations: Emerging Powers, Vol. 6 Issue 1, Winter 2005.

[20] Nollen, Stanley, "Intellectual Property in the Indian Software Industry: Past Role and Future Need", International Intellectual Property Institute (IIPI), Washington D.C., pp78, Jun 2004.

[21] Parthasarathy, Balaji, , Parayil, Govindan Ed., "The Political Economy of the Indian Software Industry", Political Economy and Information Capitalism in India, New York: Palgrave Macmillan, pp156-162, 2006.

[22] Rai, Saritha, "India's Outsourcing Industry is Facing a Labor Shortage." The New York Times, pp1-2, Feb 2006.

[23] Rogers, Everett M., Diffusion of Innovations: Fourth Edition New York: The Free Press and Simon \& Schuster Inc., pp140-142, 1995.

[24] Sen, Sumantra and Frankel, Francine, "India's Strategy of IT-Led Growth: Challenges of Asymmetric Dependence", India in Transition: Economics and Politics of Change, Center for the Advanced Study of India, University of Pennsylvania, 2005. 
[25] Thomas, T., "Change in Climate for Foreign Investment in India", Columbia Journal of World Business, Spring 94, Vol. 29, Issue 1 pg 32-40.

[26] Zenobia, Brent (Project Manager for SharpLabs India 1998-2001), Personal Interview by Brian Lininger, 14 November 2006. 